\title{
Evidence for extreme fractionation of peralkaline silicic magmas, the Boseti volcanic complex, Main Ethiopian Rift
}

\author{
Ray Macdonald • Bogusław Bagiński • \\ Fiorenzo Ronga $\cdot$ Piotr Dzierżanowski • \\ Michele Lustrino • Andrea Marzoli • Leone Melluso
}

Received: 28 April 2011 / Accepted: 21 October 2011 /Published online: 30 November 2011

(C) The Author(s) 2011. This article is published with open access at Springerlink.com

\begin{abstract}
Matrix glass and melt inclusions in phenocrysts from pantellerite lavas of the Boseti volcanic complex, Ethiopia, record extreme fractionation of peralkaline silicic magma, with $\mathrm{Al}_{2} \mathrm{O}_{3}$ contents as low as 2.3 wt.\%, $\mathrm{FeO}^{*}$ contents up to 17 wt. $\%$ and $\mathrm{SiO}_{2}$ contents $\sim 65$ wt.\%. The new data, and published data for natural and experimental glasses, suggest that the effective minimum composition for peralkaline silicic magmas has $\sim 5$ wt. $\% \mathrm{Al}_{2} \mathrm{O}_{3}, 13$ wt.\% $\mathrm{FeO}^{*}$ and $66 \pm 2$ wt.\% $\mathrm{SiO}_{2}$. The dominant fractionating assemblage is alkali feldspar+fayalite+hedenbergite+ oxides \pm quartz. Feldspar - melt relationships indicate that the feldspar is close to the minimum on the albiteorthoclase solid solution loop through the entire crystallization history. There is petrographic, mineralogical and geochemical evidence that magma mixing may have been a common process in the Boseti rhyolites.
\end{abstract}

Editorial handling: B. De Vivo

Electronic supplementary material The online version of this article (doi:10.1007/s00710-011-0184-4) contains supplementary material, which is available to authorized users.

R. Macdonald $(\bowtie) \cdot$ B. Bagiński $\cdot$ P. Dzierżanowski

IGMiP Faculty of Geology, University of Warsaw,

al. Żwirki i Wigury 93,

02-089 Warsaw, Poland

e-mail: r.macdonald@lancaster.ac.uk

F. Ronga $\cdot$ L. Melluso

Dipartimento di Scienze della Terra,

Università degli Studi di Napoli Federico II,

Via Mezzocannone 8,

80134 Naples, Italy

\section{Lustrino}

Dipartimento di Scienze della Terra,

Università degli Studi di Roma La Sapienza,

P. le A. Moro 5,

00185 Rome, Italy

\section{Introduction}

In a recent study of the basalt-peralkaline rhyolite volcanic complex Boseti (Main Ethiopian Rift; Brotzu et al. 1974, 1980), Ronga et al. (2010) found that the rhyolites had formed by prolonged crystal fractionation (90-95\%) of alkali basaltic magmas. In detail, the rhyolites represent several, closely related, liquid lines of descent, differing, for example, in the level of Al-undersaturation and in $\mathrm{Zr}$ abundances. Ronga et al. (2010) presented chemical analyses of matrix glasses in the rhyolites which are among the most Fe-rich (FeO* up to 16 wt.\%) and $\mathrm{Al}$-poor $\left(\mathrm{Al}_{2} \mathrm{O}_{3}\right.$ as low as 2.4 wt.\%) yet recorded in peralkaline rhyolites. The glasses potentially hold important information on the composition of the natural minimum point to which peralkaline silica-oversaturated magmas evolve and the



A. Marzoli

Dipartimento di Geoscienze,

Università degli Studii di Padova and IGG-CNR,

via Matteotti 30,

35100 Padova, Italy 
mineral-melt relationships operating at that point. In this paper, we provide further data on the matrix glasses, with the specific aims of assessing their significance in the evolution of peralkaline melts, and outlining, for the first time, mineral/melt relationships in such highly evolved compositions. We also comment briefly on the role of magma mixing in the evolution of the Boseti rhyolites.

\section{Geological setting}

The Boseti complex is a young volcano in the northern sector of the Main Ethiopian Rift (Fig. 1). It is composed of two coalescing main edifices, Gudda (2447 ma.s.1.) and Bariccia (2132 ma.s.l.). The volcanological history of Boseti has been described by Di Paola (1972), Brotzu et al. (1974, 1980) and Ronga et al. (2010). Activity at Boseti started with the emplacement of Pleistocene pre-caldera volcanic rocks and eruptions from centres peripheral to the main activity. Eruption of the pre-caldera rocks resulted in the formation of the main volcanic edifice and are represented by basaltic lava flows, spatter and cinder cones and peralkaline rhyolitic lava flows. This phase of activity ended with the emplacement of pantelleritic ash and pumice fall deposits. Contemporaneously with this stage, peripheral volcanism formed domes and composite cones. Caldera formation followed, now recognisable only in the western sector of the complex, resulting in the collapse of the main edifice; the younger, Gudda, edifice started to form. This post-caldera phase emplaced the largest volumes of magma in the Boseti complex. It started with the emplacement of pantelleritic lava flows which built up the Gudda edifice (Pleistocene-Holocene) and continued with eruption of peralkaline rhyolitic pumice deposits and lavas.

Almost simultaneously with the formation of Gudda, the Bariccia volcano (Pleistocene-Holocene) formed in two stages. The first stage saw the emplacement of trachyte flows followed by peralkaline trachytic and rhyolitic pumice deposits. The second stage was marked by the emplacement of pantellerite lava flows and pyroclastic deposits.

The eruptive products of Boseti display a marked bimodality, a feature found in other young central volcanoes in the Main Ethiopian Rift, such as Fantale (Gibson 1974) and Gedemsa (Peccerillo et al. 2003) (Fig. 1). Whilst arguing that the rhyolites were formed by prolonged fractional crystallisation of basalts, Ronga et al. (2010) explained the absence of intermediate rocks as a result of physical discrimination during eruptive processes.
Fig. 1 a Geological sketch map of the Boseti volcanic complex, redrawn from Brotzu et al. (1978). b Location of Boseti in the rift valley

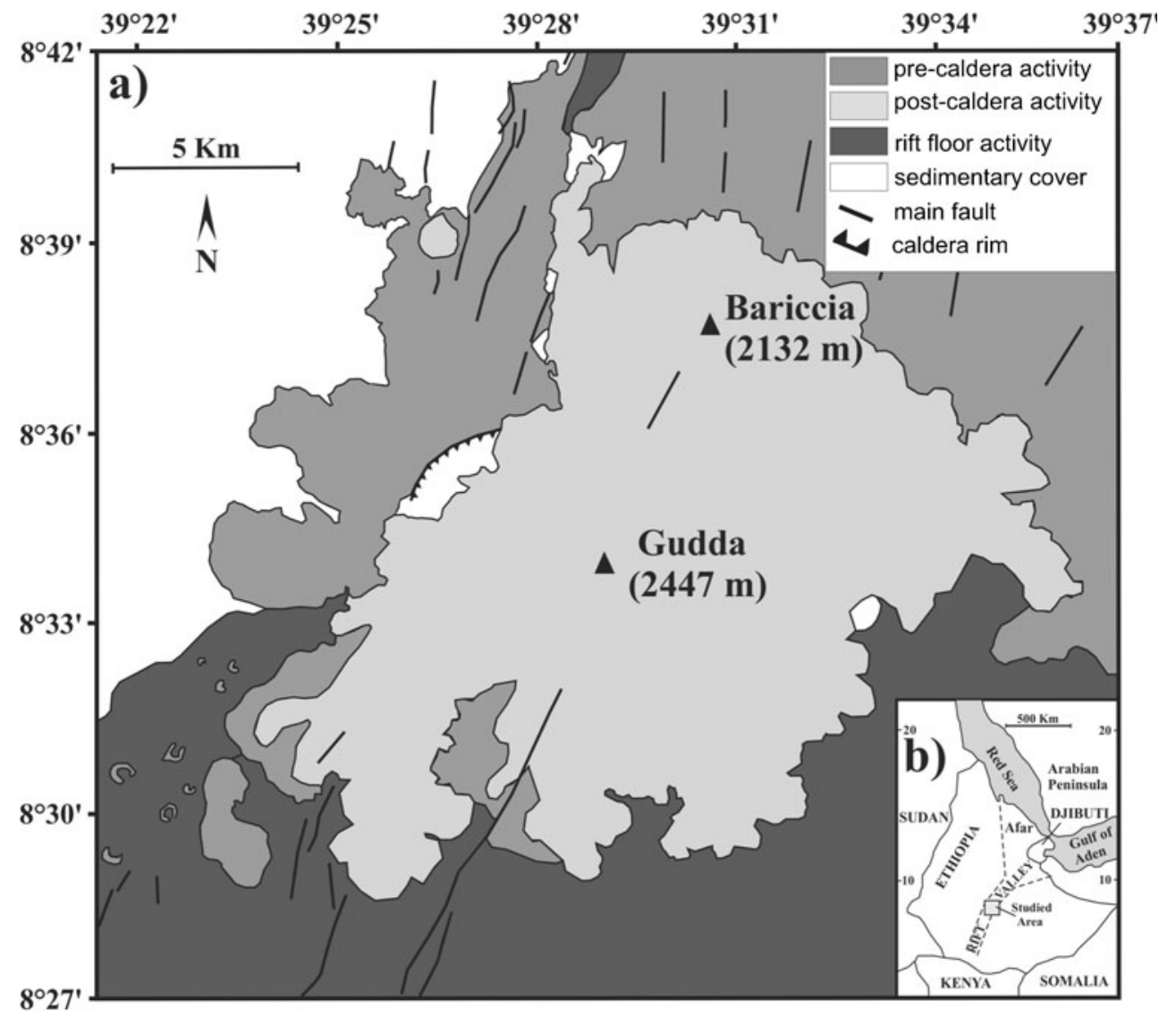




\section{Samples and analytical methods}

Four samples of peralkaline rhyolites were used in this study, B350, B354, B355 and B375, which were erupted as part of the earliest, pre-caldera, stage of activity in the complex. Whole-rock analyses of all four (Table 1), and matrix glass analyses of three, were presented in Ronga et al. (2010). The samples were selected to give a range of relationships between whole-rock, glass and phenocryst phases. Phenocryst and matrix glass compositions were determined by electron microprobe at the Inter-Institute Analytical Complex at IGMiP Faculty of Geology, University of Warsaw, using a Cameca SX-100 microprobe equipped with four wavelength detectors. The accelerating voltage was $15 \mathrm{kV}$ and the probe current was $20 \mathrm{nA}$ for pyroxene, amphibole, olivine and spinel, and $15 \mathrm{kV}$ and $10 \mathrm{nA}$ and beam spot diameter of $\sim 5 \mu \mathrm{m}$ for feldspar, to reduce $\mathrm{Na}$ loss. For glass analyses, $15 \mathrm{kV}$ and 6-10 nA and a dispersed spot of $\sim 10-20 \mu \mathrm{m}$ were used. Counting times for most elements were $20 \mathrm{~s}$ at peak and $10 \mathrm{~s}$ at background. $\mathrm{Na}$ was determined first, followed by Si. Fluorine in glass was analysed separately, using $15 \mathrm{kV}$ and $40 \mathrm{nA}$ with a dispersed spot. The standards used for glass analyses were: wollastonite for $\mathrm{Ca}$, rutile for $\mathrm{Ti}$, orthoclase for $\mathrm{K}$ and $\mathrm{Al}$, synthetic $\mathrm{Cr}_{2} \mathrm{O}_{3}$ for $\mathrm{Cr}$, albite for $\mathrm{Na}$, diopside for $\mathrm{Si}$ and $\mathrm{Mg}$, hematite for $\mathrm{Fe}$, rhodocrosite for $\mathrm{Mn}$, tugtupite for $\mathrm{Cl}$ and synthetic fluor-phlogopite for $\mathrm{F}$. For clinopyroxene and olivine, the standards were: wollastonite for $\mathrm{Si}$ and $\mathrm{Ca}$; other elements as for the glasses. Diopside was used as the $\mathrm{Ca}$ standard in feldspar analyses, with barytes for $\mathrm{Ba}$; other elements as for the glasses. The 'PAP' $\varphi(\rho Z)$ program (Pouchou and Pichoir 1991) was used for corrections. Representative and/or average analyses are

Table 1 Major (wt.\%) element analyses of study rocks

\begin{tabular}{lcrrr}
\hline & \multicolumn{1}{c}{$\mathrm{B} 350$} & \multicolumn{1}{c}{$\mathrm{B} 354$} & \multicolumn{1}{c}{$\mathrm{B} 355$} & \multicolumn{1}{c}{$\mathrm{B} 375$} \\
\hline $\mathrm{SiO}_{2}$ & 69.45 & 69.66 & 67.02 & 67.48 \\
$\mathrm{TiO}_{2}$ & 0.57 & 0.55 & 0.61 & 0.58 \\
$\mathrm{Al}_{2} \mathrm{O}_{3}$ & 8.56 & 7.60 & 11.55 & 9.52 \\
$\mathrm{Fe}_{2} \mathrm{O}_{3} *$ & 10.05 & 10.18 & 8.98 & 9.82 \\
$\mathrm{MnO}$ & 0.30 & 0.30 & 0.36 & 0.41 \\
$\mathrm{MgO}$ & 0.00 & 0.00 & 0.08 & 0.53 \\
$\mathrm{CaO}$ & 0.38 & 0.42 & 0.35 & 0.90 \\
$\mathrm{Na}$ & 6.24 & 5.70 & 6.02 & 4.57 \\
$\mathrm{~K}_{2} \mathrm{O}$ & 4.23 & 4.25 & 3.84 & 4.06 \\
$\mathrm{P}_{2} \mathrm{O}_{5}$ & 0.02 & 0.02 & 0.04 & 0.03 \\
$\mathrm{LOI}$ & 0.21 & 1.32 & 1.14 & 2.10 \\
$\mathrm{Total}$ & 100.0 & 100.0 & 100.0 & 100.0 \\
$\mathrm{PI}$ & 1.73 & 1.84 & 1.22 & 1.25 \\
\hline
\end{tabular}

$\mathrm{Fe}_{2} \mathrm{O}_{3}{ }^{*}$, total $\mathrm{Fe}$ as $\mathrm{Fe}^{3+} . P I$, Peralkalinity Index

Data from Ronga et al. (2010) presented in Tables 2, 3 and 4; the full data sets are given in Supplementary Tables 1 and 2, available as electronic supplementary material to this paper.

\section{Petrography and nomenclature}

The samples studied have CIPW normative quartz $(q)$ between $17 \%$ and $31 \%$. Taking the trachyte-rhyolite boundary at the conventional $10 \% q$, all samples are classified as rhyolites. Their peralkalinity indices (PI= mol. $\left.\left(\mathrm{Na}_{2} \mathrm{O}+\mathrm{K}_{2} \mathrm{O}\right) / \mathrm{Al}_{2} \mathrm{O}_{3}\right)$ range from 1.22 to 1.84 (Ronga et al. 2010) and according to the classification scheme of Macdonald (1974a), they are pantellerites.

Comendites, less peralkaline rhyolites with generally lower $\mathrm{FeO}^{*}$ and higher $\mathrm{Al}_{2} \mathrm{O}_{3}$ contents, are also present in the suite (Ronga et al. 2010). Below, we give a short petrographic description of each sample.

B350 Dark brown and grey glassy components of different composition are patchily and streakily intermingled (Fig. 2a). Subhedral to euhedral alkali feldspar phenocrysts up to $2 \mathrm{~mm}$ across occur in both components but are more common in the darker type. Some feldspars contain melt inclusions (Fig. 3b). There are rare, green pyroxene phenocrysts. A sulphide phase occurs mainly as inclusions in feldspar and pyroxene; one microphenocryst in the matrix has an unusual torpedo shape (Fig. 3a). Both darker and lighter components contain small $(<10 \mu \mathrm{m})$ patches of glass, especially associated with feldspar phenocrysts.

B354 There are three glassy matrix components of different composition (Fig. 2b,c). A dark brown component (1) is streakily intermingled with a grey material (component 2). The third component is very dark, almost black, and mainly occurs mingled with component 1 . In places, component 1 forms a rim between component 3 and a fourth material, which is light-coloured, flow-banded and charged with microlites of pyroxene and aenigmatite. The various components are mixed at scales between tens of mms and cms. Euhedral to subhedral phenocrysts, sometimes partially resorbed, of alkali feldspar up to $1 \mathrm{~mm}$ occur in components 1 and 4.

B355 This sample contains $20 \%$ of alkali feldspar, clinopyroxene, olivine, FeTi-oxide and apatite phenocrysts. Alkali feldspar is dominant, forming euhedral to subhedral plates up to $4 \mathrm{~mm}$ long. Some contain melt inclusions. Green pyroxene prisms are up to $3.3 \mathrm{~mm}$ long. Prismatic olivine grains $(\leq 1.5 \mathrm{~mm})$ are commonly partly resorbed. Equant oxides $(\leq 0.2 \mathrm{~mm})$ tend to occur in clusters with the other mafic phenocrysts. Apatite crystals $(\leq 0.1 \mathrm{~mm})$ are invariably included in olivine and pyroxene. Sulphide 
Table 2 EMP analyses of alkali feldspars

\begin{tabular}{|c|c|c|c|c|c|c|c|c|c|c|c|}
\hline \multirow[t]{2}{*}{ Sample } & \multicolumn{2}{|l|}{ B355 } & \multicolumn{3}{|l|}{ B350 } & \multicolumn{2}{|l|}{ B354 } & \multicolumn{4}{|l|}{ B375 } \\
\hline & 1 & 2 & 3 & 4 & 5 & 6 & 7 & 8 & 9 & 10 & 11 \\
\hline $\mathrm{SiO}_{2}$ & 67.35 & 67.12 & 66.83 & 67.01 & 66.36 & 66.19 & 66.92 & 67.18 & 67.23 & 67.14 & 68.42 \\
\hline $\mathrm{Al}_{2} \mathrm{O}_{3}$ & 18.92 & 17.97 & 18.10 & 17.97 & 12.43 & 17.79 & 17.93 & 18.13 & 17.43 & 16.03 & 14.90 \\
\hline $\mathrm{Fe}_{2} \mathrm{O}_{3} *$ & 0.30 & 0.58 & 0.78 & 0.89 & 8.45 & 1.22 & 0.87 & 0.96 & 2.01 & 3.93 & 5.08 \\
\hline $\mathrm{CaO}$ & 0.32 & 0.08 & 0.01 & 0.01 & b.d. & 0.01 & 0.01 & 0.16 & 0.10 & 0.11 & 0.35 \\
\hline $\mathrm{BaO}$ & 0.19 & 0.03 & 0.03 & 0.03 & 0.03 & b.d. & 0.03 & 0.41 & 0.18 & 0.16 & 0.09 \\
\hline $\mathrm{Na}_{2} \mathrm{O}$ & 7.78 & 7.36 & 7.60 & 7.65 & 7.55 & 7.42 & 7.57 & 7.93 & 7.60 & 7.33 & 6.10 \\
\hline $\mathrm{K}_{2} \mathrm{O}$ & 5.27 & 6.13 & 6.11 & 5.82 & 4.87 & 6.77 & 6.34 & 4.96 & 5.94 & 5.98 & 5.66 \\
\hline Total & 100.13 & 99.27 & 99.47 & 99.37 & 99.69 & 99.40 & 99.67 & 99.73 & 100.48 & 100.68 & 100.60 \\
\hline \multicolumn{12}{|c|}{ Formulae based on 8 oxygens } \\
\hline $\mathrm{Si}$ & 2.996 & 3.020 & 3.006 & 3.013 & 3.039 & 2.996 & 3.009 & 3.017 & 3.007 & 3.053 & 3.060 \\
\hline $\mathrm{Al}$ & 0.992 & 0.953 & 0.960 & 0.952 & 0.671 & 0.949 & 0.950 & 0.959 & 0.919 & 0.859 & 0.786 \\
\hline $\mathrm{Fe}^{3+}$ & 0.010 & 0.020 & 0.026 & 0.030 & 0.291 & 0.042 & 0.030 & 0.016 & 0.068 & 0.067 & 0.171 \\
\hline $\mathrm{Ca}$ & 0.015 & 0.004 & 0.001 & 0.001 & 0.000 & 0.000 & 0.000 & 0.008 & 0.005 & 0.005 & 0.017 \\
\hline $\mathrm{Ba}$ & 0.003 & 0.001 & 0.001 & 0.001 & 0.001 & 0.000 & 0.001 & 0.007 & 0.003 & 0.003 & 0.002 \\
\hline $\mathrm{Na}$ & 0.671 & 0.642 & 0.663 & 0.667 & 0.670 & 0.651 & 0.660 & 0.691 & 0.659 & 0.646 & 0.529 \\
\hline K & 0.299 & 0.352 & 0.351 & 0.334 & 0.285 & 0.391 & 0.364 & 0.284 & 0.339 & 0.347 & 0.323 \\
\hline$\Sigma$ cations & 5.0 & 5.0 & 5.0 & 5.0 & 5.0 & 5.0 & 5.0 & 5.0 & 5.0 & 5.0 & 4.9 \\
\hline Or & 30.4 & 35.3 & 34.6 & 33.3 & 29.8 & 36.4 & 35.5 & 28.9 & 33.9 & 34.8 & 37.2 \\
\hline $\mathrm{Ab}$ & 68.1 & 64.3 & 65.4 & 66.6 & 70.2 & 63.6 & 64.5 & 70.3 & 65.6 & 64.7 & 60.9 \\
\hline An & 1.5 & 0.4 & 0.1 & 0.1 & 0.0 & 0.0 & 0.0 & 0.7 & 0.5 & 0.5 & 1.9 \\
\hline
\end{tabular}

1, 2 lowest and highest Or contents in phenocrysts; 3, 4 average of phenocrysts in dark and light glass, respectively; 5 high-Fe in phenocryst contacting melt inclusion; 6, 7 average of phenocrysts in dark and light glass, respectively; 8, 9 average of phenocrysts in dark and light glass, respectively; 10 matrix feldspar contacting glass: 11 rim of phenocryst. $\mathrm{Fe}_{2} \mathrm{O}_{3} *$ is total $\mathrm{Fe}$ as $\mathrm{Fe}^{3+}$

crystals also occur in pyroxene. The matrix, composed of the same phases as the phenocrysts plus quartz, is largely hypocrystalline, with grain sizes ranging from microphenocrysts to microlites, and contains rare, small $(<20 \mu \mathrm{m})$ pools of colourless glass.

B375 This sample contains two, darker and lighter, patchily mingled glassy matrix components of different composition (Fig. 2d). Composed of the same minerals, the darker component is richer in pyroxene microcrysts. The same phenocryst assemblage (15\% modally) occurs in both components. It is dominated by subhedral alkali feldspar up to $3 \mathrm{~mm}$ in size, commonly forming clusters. Some show shadowy extinction. Prismatic clinopyroxene phenocrysts, up to $1 \mathrm{~mm}$ long, are zoned to bright green rims. There are rare olivine, aenigmatite, FeTi-oxide and sulphide (micro)phenocrysts. Although the matrix is almost completely crystalline, pristine glass occurs in two forms: as small $(\leq 20 \mu \mathrm{m})$ irregular patches attached to the rims of feldspar phenocrysts and as larger $(\leq 100 \mu \mathrm{m})$ pools in the matrix (Fig. 2d). The glass is associated, in the matrix, with alkali feldspar, aegirine-augite, aenigmatite, quartz and tiny grains of ilmenite (Fig. 3d). Small pools of carbonate are scattered in the matrix (Fig. 3c).
Since alkali feldspar is the sole phenocryst phase in B354, it can be assumed that it was the liquidus mineral in all samples. However, the fact that the feldspar may include phenocrysts of the mafic phases suggests that it was joined by them in the crystallizing assemblage. Although many phenocrysts are euhedral and unzoned, some subhedral partly resorbed crystals are found in three of the rocks, consistent with the evidence of magma mingling in those samples.

\section{Mineral chemistry}

\section{Alkali feldspar}

The total compositional range of the new data (Table 2; Supplementary Table 1) is $\mathrm{Or}_{28.1-40.6} \mathrm{Ab}_{58.2-70.6} \mathrm{An}_{0 \cdot 0-1.9}$, i.e. compositionally the feldspars straddle the anorthoclasesanidine boundary (Fig. 4). Calcium levels are very low $\left(\mathrm{An}_{0-2}\right)$. Additionally, Ronga et al. (2010) recorded phenocryst core compositions of $\mathrm{Or}_{19.1} \mathrm{Ab}_{80.7} \mathrm{An}_{0.3}$ in $\mathrm{B} 355$, and $\mathrm{Or}_{15.5} \mathrm{Ab}_{81.1} \mathrm{An}_{3.5}$ in $\mathrm{B} 175$ (comendite; not analysed here). 
Table 3 Representative EMP analyses of olivine and clinopyroxene phenocrysts

\begin{tabular}{|c|c|c|c|c|c|c|c|c|c|c|}
\hline \multirow[t]{3}{*}{ Sample } & \multicolumn{4}{|l|}{ Olivine } & \multicolumn{4}{|c|}{ Clinopyroxene } & & \\
\hline & \multicolumn{4}{|l|}{ B355 } & \multicolumn{4}{|l|}{ B355 } & \multicolumn{2}{|l|}{ B350 } \\
\hline & Near rim & Intermed. & Intermed. & Rim & Core & Intermed. & Rim & Core & Rim & Core \\
\hline $\mathrm{SiO}_{2}$ & 29.43 & 29.53 & 29.27 & 29.24 & 47.81 & 47.27 & 47.12 & 49.55 & 48.16 & 47.98 \\
\hline $\mathrm{TiO}_{2}$ & b.d. & 0.04 & 0.05 & 0.02 & 0.65 & 0.61 & 0.67 & 0.71 & 0.47 & 0.50 \\
\hline $\mathrm{Al}_{2} \mathrm{O}_{3}$ & - & - & - & - & 0.34 & 0.33 & 0.31 & 1.09 & 0.10 & 0.12 \\
\hline $\mathrm{V}_{2} \mathrm{O}_{3}$ & - & - & - & - & 0.02 & 0.02 & 0.04 & 0.01 & b.d. & 0.05 \\
\hline $\mathrm{Cr}_{2} \mathrm{O}_{3}$ & 0.02 & 0.03 & b.d. & 0.04 & b.d. & b.d. & 0.03 & 0.02 & 0.03 & b.d. \\
\hline $\mathrm{FeO}^{*}$ & 64.89 & 64.69 & 64.91 & 64.62 & 27.37 & 29.60 & 28.77 & 19.49 & 30.07 & 30.60 \\
\hline $\mathrm{MnO}$ & 5.56 & 5.21 & 5.35 & 5.42 & 2.05 & 1.97 & 1.92 & 1.64 & 1.44 & 1.48 \\
\hline $\mathrm{MgO}$ & 0.64 & 0.63 & 0.75 & 0.7 & 1.60 & 0.63 & 1.13 & 6.80 & 0.12 & 0.10 \\
\hline $\mathrm{NiO}$ & b.d. & 0.03 & b.d. & b.d. & b.d. & b.d. & b.d. & b.d. & b.d. & 0.02 \\
\hline $\mathrm{CaO}$ & 0.68 & 0.61 & 0.76 & 0.63 & 19.90 & 19.19 & 19.60 & 20.08 & 17.99 & 17.52 \\
\hline $\mathrm{Na}_{2} \mathrm{O}$ & - & - & - & - & 0.54 & 0.66 & 0.52 & 0.56 & 1.42 & 1.57 \\
\hline Total & 101.22 & 100.77 & 101.09 & 100.67 & 100.28 & 100.28 & 100.11 & 99.95 & 99.80 & 99.94 \\
\hline \multicolumn{5}{|c|}{ Formulae based on 4 oxygens } & \multicolumn{6}{|c|}{ Formulae based on 6 oxygens } \\
\hline $\mathrm{Si}$ & 0.985 & 0.99 & 0.981 & 0.984 & 1.949 & 1.943 & 1.935 & 1.946 & 1.981 & 1.971 \\
\hline $\mathrm{Ti}$ & 0.000 & 0.001 & 0.001 & 0.001 & 0.020 & 0.019 & 0.021 & 0.021 & 0.015 & 0.015 \\
\hline $\mathrm{Al}$ & - & - & - & - & 0.016 & 0.016 & 0.015 & 0.050 & 0.005 & 0.006 \\
\hline V & - & - & - & - & 0.001 & 0.001 & 0.001 & 0.000 & 0.000 & 0.001 \\
\hline $\mathrm{Cr}$ & 0.001 & 0.001 & b.d. & 0.001 & 0.000 & 0.000 & 0.001 & 0.001 & 0.001 & 0 \\
\hline $\mathrm{Fe}^{3+}$ & - & - & - & - & 0.088 & 0.113 & 0.113 & 0.057 & 0.117 & 0.145 \\
\hline $\mathrm{Fe}^{2+}$ & 1.816 & 1.814 & 1.819 & 1.818 & 0.846 & 0.904 & 0.875 & 0.583 & 0.918 & 0.905 \\
\hline $\mathrm{Mn}$ & 0.158 & 0.148 & 0.152 & 0.154 & 0.071 & 0.069 & 0.067 & 0.055 & 0.05 & 0.051 \\
\hline $\mathrm{Mg}$ & 0.032 & 0.031 & 0.037 & 0.035 & 0.097 & 0.039 & 0.069 & 0.398 & 0.007 & 0.006 \\
\hline $\mathrm{Ni}$ & 0.000 & 0.001 & 0.000 & 0.000 & 0.000 & 0.000 & 0.000 & 0.000 & 0.000 & 0.001 \\
\hline $\mathrm{Ca}$ & 0.024 & 0.022 & 0.027 & 0.023 & 0.869 & 0.845 & 0.862 & 0.845 & 0.793 & 0.771 \\
\hline $\mathrm{Na}$ & - & - & - & - & 0.043 & 0.053 & 0.041 & 0.043 & 0.114 & 0.125 \\
\hline Cations & 3.0 & 3.0 & 3.0 & 3.0 & 4.0 & 4.0 & 4.0 & 4.0 & 4.0 & 4.0 \\
\hline Fo mol.\% & 1.7 & 1.7 & 2 & 1.9 & - & - & - & - & - & - \\
\hline $\mathrm{Ca}$ & - & - & - & - & 45.8 & 44.5 & 44.9 & 44.9 & 43.2 & 42.2 \\
\hline $\mathrm{Mg}$ & - & - & - & - & 5.1 & 2.0 & 3.6 & 21.1 & 0.4 & 0.3 \\
\hline $\mathrm{Fe}^{2+}$ & - & - & - & - & 49.1 & 53.5 & 51.5 & 34.0 & 56.4 & 57.5 \\
\hline
\end{tabular}

b.d. below detection; dash not determined; $\mathrm{FeO}^{*}$ all $\mathrm{Fe}$ as $\mathrm{Fe}^{2+}$; Intermed. point intermediate between core and rim; $\mathrm{Fe}^{3+}$ and $\mathrm{Fe}^{2+}$ calculated on basis of stoichiometry

There is very considerable overlap between specimens but there are small differences in average composition in different rocks and/or different glass in the same rock, e.g. B355 $\mathrm{Or}_{30.4}$ $\mathrm{Ab}_{68.1} \mathrm{An}_{1.5}$; $\mathrm{B} 375$ light glass $\mathrm{Or}_{33.9} \mathrm{Ab}_{65.6} \mathrm{An}_{0.5}$, dark glass $\mathrm{Or}_{28.9} \mathrm{Ab}_{70.3} \mathrm{An}_{0.7}$; B350 light glass $\mathrm{Or}_{33.3} \mathrm{Ab}_{66.6} \mathrm{An}_{0.1}$, dark glass $\mathrm{Or}_{34.6} \mathrm{Ab}_{65.4} \mathrm{An}_{0.1}$; $\mathrm{B} 354$ dark glass $\mathrm{Or}_{36.4} \mathrm{Ab}_{63.6} \mathrm{An}_{0.0}$, light glass $\mathrm{Or}_{35.5} \mathrm{Ab}_{64.5} \mathrm{An}_{0.0}$ (Table 2). The value for $\mathrm{B} 375$ (dark glass) is probably anomalous; it refers to data from one crystal in immediate contact with a melt inclusion. Individual crystals show internal variation of up to $2-$ $8 \mathrm{~mol} \%$ Or; in most cases, the variation is not systematic but slight rimward enrichment in either $\mathrm{K}$ or $\mathrm{Na}$ is occasionally seen. Areas of high $\mathrm{Fe}_{2} \mathrm{O}_{3}$ contents up to 5.08 wt.\% occur as either cores (B350) or rims (B375) to some phenocrysts (Table 2); they normally appear brighter on BSE images. So far as we know, these are the highest $\mathrm{Fe}$ values yet recorded in feldspars in peralkaline rhyolites, although Troll and Schmincke (2002) have recorded feldspars with up to 4 wt. $\% \mathrm{Fe}_{2} \mathrm{O}_{3}$ in comendites from Gran Canaria. The most extreme $\mathrm{Fe}$ enrichment occurs in a feldspar phenocryst in $\mathrm{B} 350$, where the feldspar contacting a melt inclusion has $8.45 \mathrm{wt} . \% \mathrm{Fe}_{2} \mathrm{O}_{3}$ * (0.29 apfu), decreasing to $0.91 \mathrm{wt} \% \%(0.03 \mathrm{apfu})$ at $\sim 10 \mu \mathrm{m}$ from the inclusion. The high-Fe feldspar gives an acceptable 


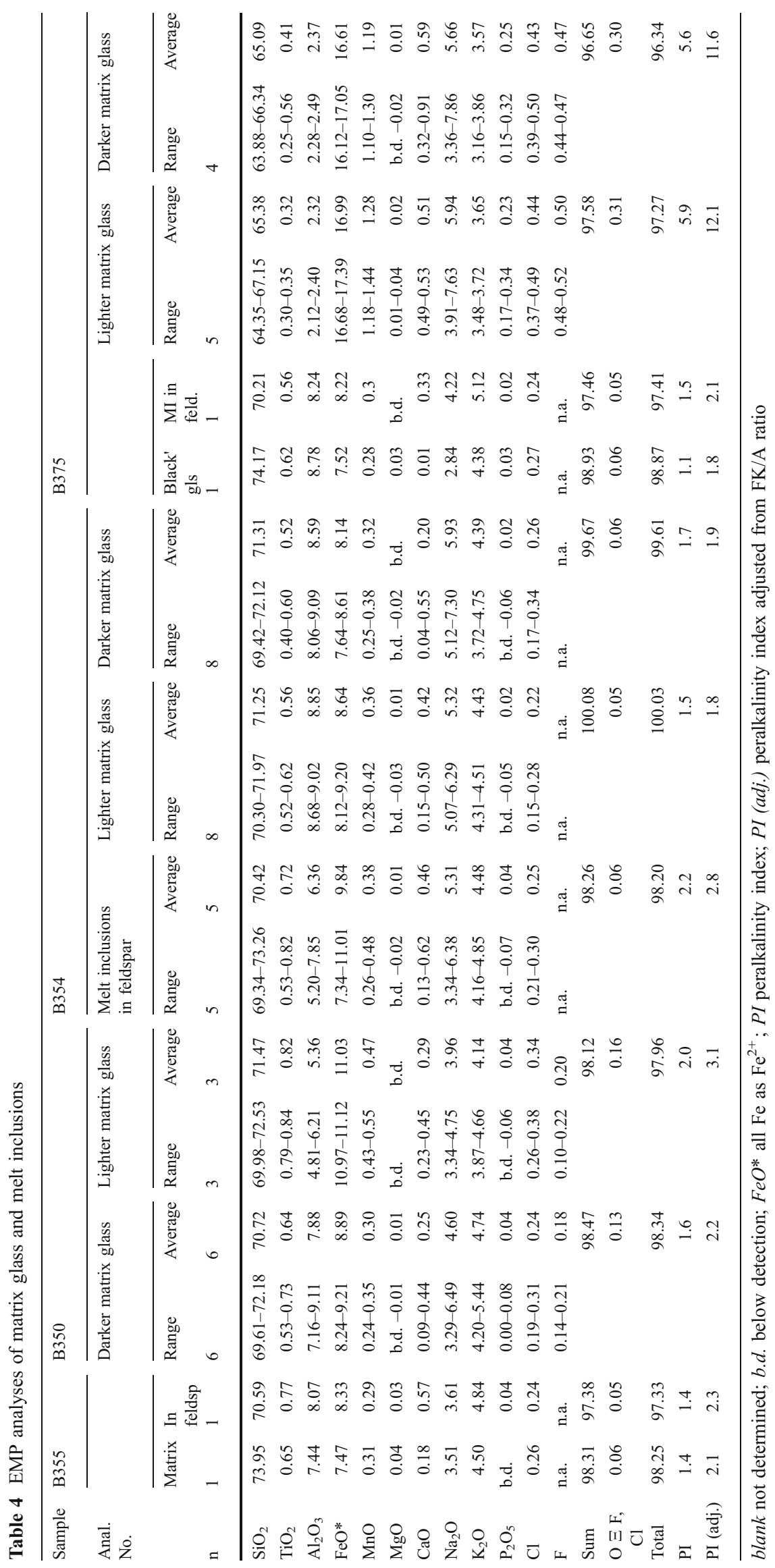


Fig. 2 Photomicrographs showing textural evidence of magma mixing in Boseti rhyolites. a Streaky mingling of lighter and darker components, B350. b At least three components in B354. c Dark border forming boundary between lighter and darker components in B354. d Mingling of darker and lighter components partially obscured by devitrification of both components. Plane-polarised light used in all
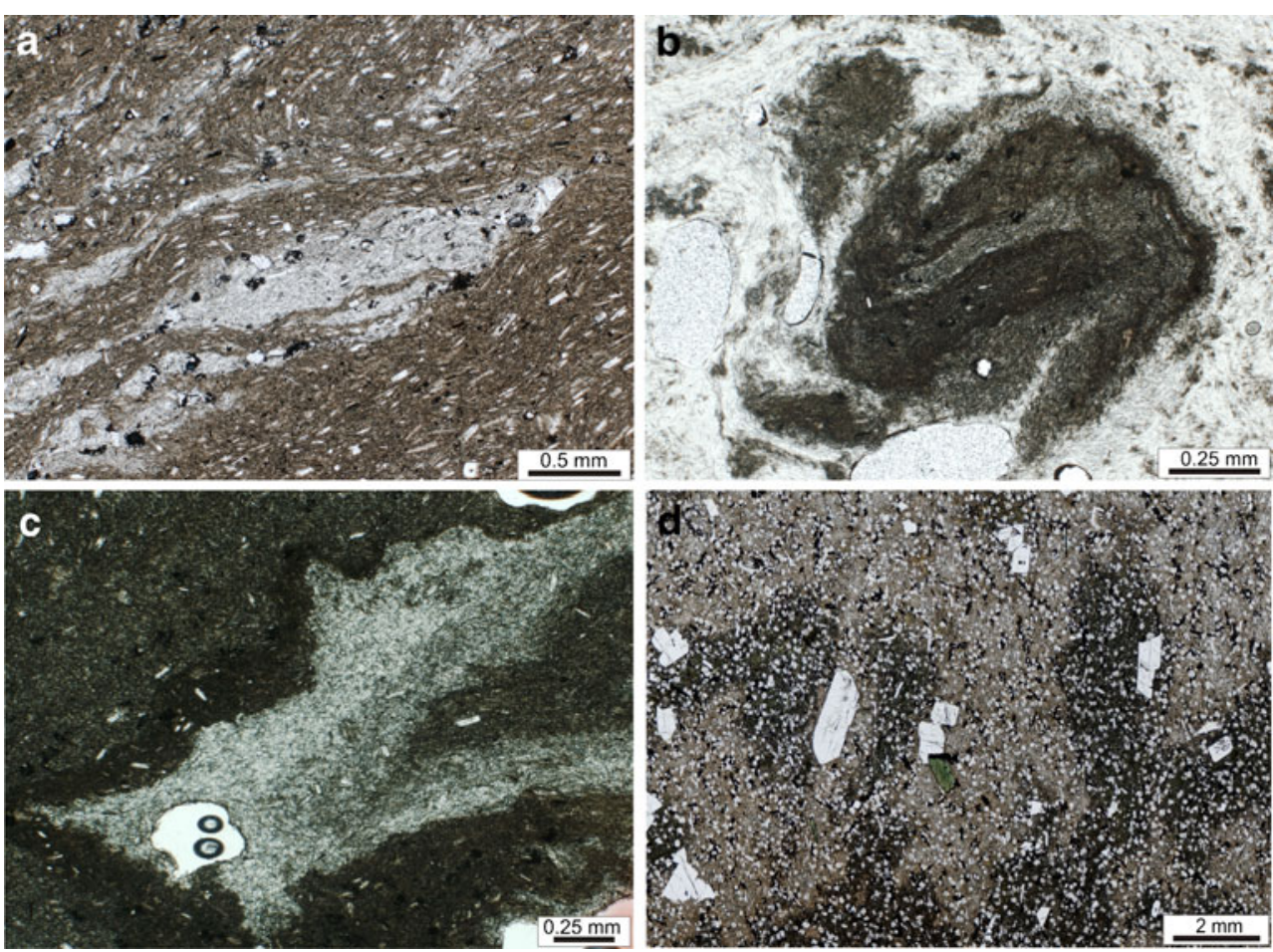

formula (Table 2; Supplementary Table 1) and we do not believe that its composition is an artefact of its closeness to the melt inclusion.

In the feldspars, the Fe almost exactly balances the Aldeficiency, i.e. $\left(\mathrm{Al}+\mathrm{Fe}^{3+}\right) \approx 1$ apfu. The entry of $\mathrm{Fe}$ into the feldspar is apparently controlled by composition, particularly by host-rock peralkalinity, and not by such parameters as $f_{2}$.
Olivine

Our new data for olivine phenocrysts in B355 (Table 3; Supplementary Table 2) show a very narrow compositional range, $\mathrm{Fo}_{1.5-2.4}$, comparable to the value of $\mathrm{Fo}_{1.1}$ reported by Ronga et al. (2010). The total range in the Boseti rhyolites is $\mathrm{Fo}_{10-1}$, the minerals becoming more Fe-rich

Fig. 3 BSE images of selected mineralogical features. a Unusual, torpedo-shaped sulphide microphenocryst in B350. b Partially devitrified melt inclusion in feldspar phenocryst in B350. c Carbonate with glass rims, interstitial to alkali feldspar in matrix, B375. d Matrix wedge between two feldspar phenocrysts, B375. Glass forms pools in the matrix and along contact with phenocrysts. Other phases are aegirine-augite (px), sanidine (Kfs), quartz (Q), aenigmatite (Aen) and ilmenite (Ilm)
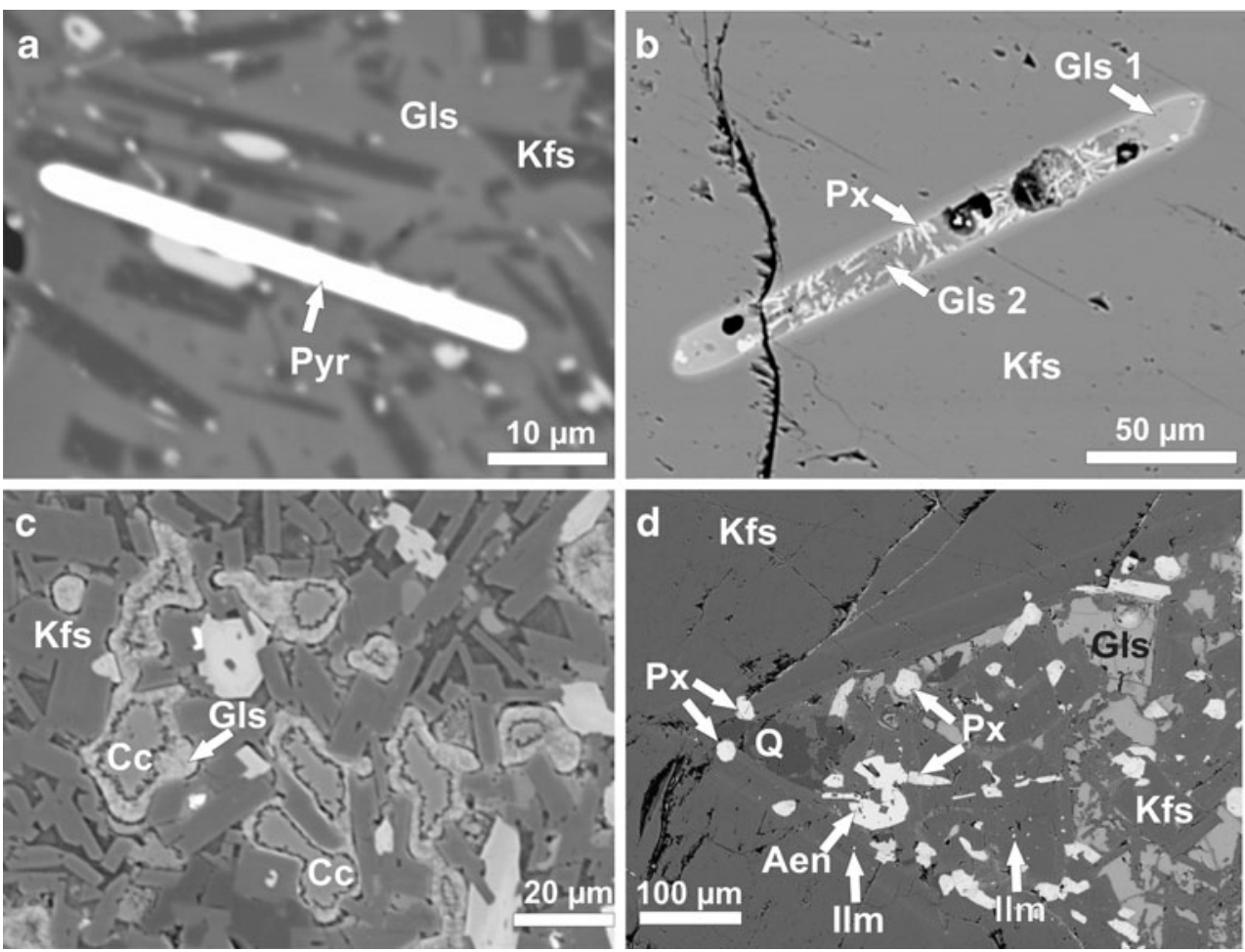


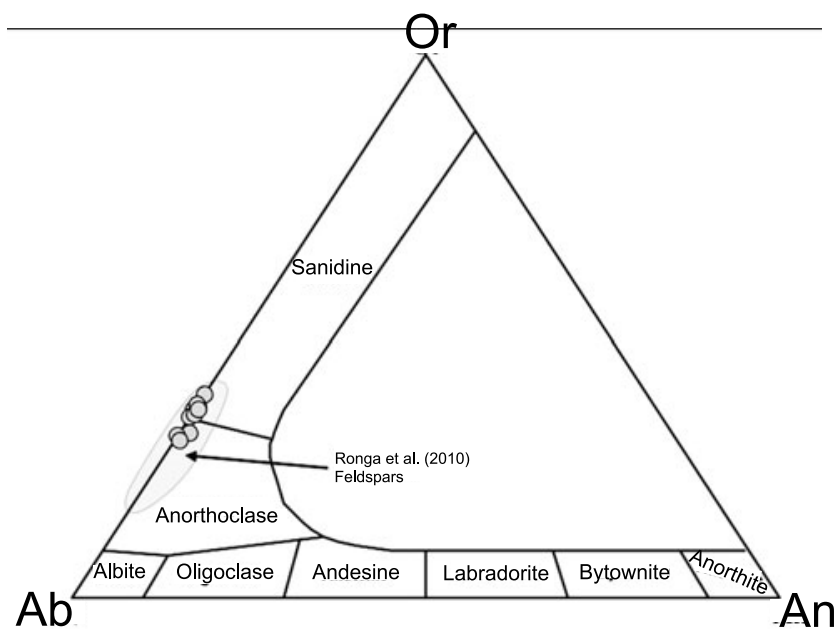

Fig. 4 Feldspar phenocrysts from Boseti plotted in the An-Ab-Or diagram. The shaded field is for feldspars from the wider sample coverage by Ronga et al. (2010)

with increasing whole-rock peralkalinity (Ronga et al. 2010). MnO contents of olivine are up to $5.71 \mathrm{wt} . \%$, in comendite B175 (Ronga et al. 2010). Although it has been known since the work of Carmichael (1962) that olivine in peralkaline rhyolites is Mn-rich, the Boseti values are, so far as we know, the highest yet recorded. $\mathrm{CaO}$ abundances range from $\sim 0.6$ wt.\% to 0.8 wt. $\%(0.022-0.027 \mathrm{apfu})$ and decrease with increasing $\mathrm{Fa}$ content of the olivine (c.f. Ronga et al. 2010).

Using average olivine and melt compositions, the meltliquid exchange distribution coefficients $\left(\mathrm{K}_{\mathrm{D}}\right)$ for $\mathrm{Fe}-\mathrm{Mg}$ is 0.50 . This fits in very well to the overall trend of increasing $\mathrm{K}_{\mathrm{D}}$ with increasing glass peralkalinity in peralkaline trachytes and rhyolites (Fig. 5). They are also in accord with the observation that olivine $\mathrm{K}_{\mathrm{D}}$ values vary with bulk

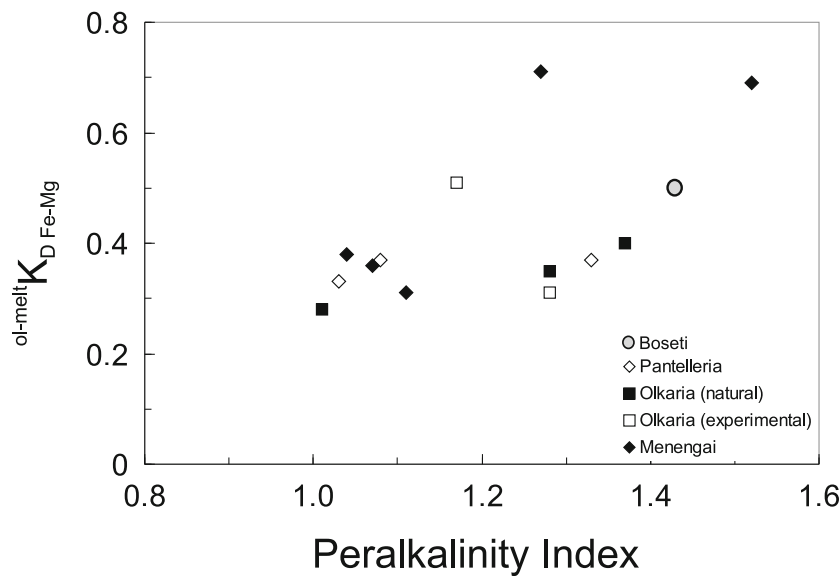

Fig. 5 olivine-melt $\mathrm{K}_{\mathrm{DFe}-\mathrm{Mg}}$ plotted against peralkalinity index of the coexisting glass for peralkaline trachytes and rhyolites. Data sources: Boseti, this paper; Pantelleria, Mahood and Stimac (1990); Olkaria natural rocks, Marshall et al. (2009); Olkaria experimental glasses, Scaillet and Macdonald (2003); Menengai, Macdonald et al. (2011) rock composition, from $\sim 0.3$ in basalts (Roeder and Emslie 1970; Ulmer 1989) to as high as 0.68 in silicic rocks (Sisson and Grove 1993; Kilinc and Gerke 2003).

\section{Clinopyroxene}

The compositional range in the clinopyroxene phenocrysts is small, $\mathrm{Ca}_{45.8-42.2} \mathrm{Mg}_{5.1-0.2} \mathrm{Fe}_{49.1-57.5}$ crystals becoming more Fe-rich with increasing whole-rock peralkalinity (Table 3; Supplementary Table 2). Crystals are usually very homogeneous; occasionally, reversed zoning is seen, e. g. $\mathrm{Ca}_{43.3} \mathrm{Mg}_{1.2} \mathrm{Fe}_{55.5}$ to $\mathrm{Ca}_{45.6} \mathrm{Mg}_{2.9} \mathrm{Fe}_{51.6}$ from core to rim in a crystal in B355, whereas Ronga et al. (2010) recorded strong core to rim $\mathrm{Fe}$-enrichment $\left(\mathrm{Ca}_{40.9} \mathrm{Mg}_{10.8} \mathrm{Fe}_{48.3}\right.$ to $\left.\mathrm{Ca}_{42.3} \mathrm{Mg}_{0.5} \mathrm{Fe}_{57.3}\right)$ in a phenocryst from pantellerite B345 (not studied here). Levels of $\mathrm{Na}_{2} \mathrm{O}$ are low, $<2 \mathrm{wt} . \%$, even in the most Fe-rich crystals. Ronga et al. (2010) reported aegirine-augite rims (with $\mathrm{Na}_{2} \mathrm{O}$ up to 5.2 wt.\%) to hedenbergite cores in Boseti pantellerites but, in this study, aegirine-augite and aegirine were found only as matrix phases (Supplementary Table 2). This is in accord with the general situation in peralkaline rhyolites; hedenbergite is the normal pyroxene phenocryst even in the most strongly peralkaline rocks, aegirine-augite being recorded only rarely (Macdonald et al. 2011). This is probably related to the relatively low $f \mathrm{O}_{2}$ at which the magmas evolve, at or close to FMQ (Scaillet and Macdonald 2001, 2003, 2006; White et al. 2005, 2009; Ren et al. 2006; Di Carlo et al. 2010). A microphenocryst in B355 has a relatively magnesian core $\left(\mathrm{Ca}_{44.9} \mathrm{Mg}_{21.1} \mathrm{Fe}_{34.0}\right)$, which may represent a highertemperature phase of magmatic evolution or mixing of the pantellerite with a more trachytic magma.

The extremely low $\mathrm{MgO}$ contents in both the pyroxene and glass in strongly peralkaline pantelleritic rocks, commonly around the analytical detection limits, makes it difficult to determine melt-liquid exchange distribution coefficients $\left(\mathrm{K}_{\mathrm{D}}\right)$ for Fe-Mg accurately. Using the average rim compositions of pyroxene phenocrysts and of matrix glass (below) in B355, the Fe-Mg $\mathrm{K}_{\mathrm{D}}$ is 0.14 . This is in line with values determined for other peralkaline trachytes and rhyolites from Pantelleria, Italy (0.12-0.16; Carmichael 1962; Mahood and Stimac 1990; Di Carlo et al. 2010). These $K_{D}$ values are lower than those in mafic and intermediate rocks, which are normally in the range 0.20 0.30 (Sisson and Grove 1993; Putirka et al. 2003).

\section{FeTi-oxides}

In peralkaline trachytes and rhyolites, the spinel and rhombohedral phases occur in broadly the same range of rocks, covering the spectrum of whole-rock compositions. It is seldom clear in peralkaline rhyolites what stabilises one oxide over the other (Macdonald et al. 2011). In the 
Boseti rocks, an oxide phase occurs as phenocrysts only in B355, where it takes two forms: in one, titanomagnetite ( $\left.X_{\text {usp }} 70.4\right)$ rims ilmenite $\left(X_{\mathrm{ilm}} 96.5\right)$ and in the second, it is a matrix phase $\left(X_{\text {usp }} 66.8\right)$ of much later crystallization than the ilmenite $\left(X_{\mathrm{ilm}}\right.$ 94.9-95.6) enclosed in an adjacent olivine. It might appear, therefore, that at Boseti the titanomagnetite is stabilised, relative to ilmenite, in lower temperature, more peralkaline melts. However, tiny rounded grains of ilmenite occur in the matrix of B375 (Fig. 3d) and must have crystallized (although not necessarily in equilibrium) when the residual melt was extremely peralkaline.

\section{Apatite}

Analyses of euhedral apatite crystals included in a fayalite phenocryst in B355 are given in Supplementary Table 1. They are fluorapatites with up to $\sim 5 \%$ of the britholite-(Ce) component via the substitution scheme $\mathrm{Ca}^{2+}+\mathrm{P}^{5+}=\mathrm{REE}^{3+}+$ $\mathrm{Si}^{4+}$. Published analyses of apatite phenocrysts in peralkaline rocks are scarce. Macdonald et al. (2008a) found up to 35\% britholite component in apatites in comendites of the Olkaria complex, Kenya. In contrast, Mahood and Stimac (1990) found lower enrichment in the britholite component in apatites from Pantellerian trachytes and pantellerites, with $\mathrm{REE}+\mathrm{Si} \leq 0.5 \mathrm{apfu}$, and Macdonald et al. (2011) recorded solid solution towards britholite-(Ce) up to $7 \mathrm{~mol} \%$ in apatites from pantelleritic trachytes of the Menengai volcano, Kenya. The reasons why apatites from the more strongly peralkaline (pantelleritic) rocks are less REE-enriched than those from the more mildly peralkaline (comenditic) rocks, at least as exemplified by the Olkaria suite, are not yet known.

\section{Sulphide}

Due to its small size, we were not able to produce quantitative analyses of the sulphides. Semi-quantitative analyses indicate, however, that it is pyrrhotite, which has also been recorded as microphenocrysts in peralkaline rhyolites from Tejeda volcano, Gran Canaria (Crisp and Spera 1987), Pantelleria (Lowenstern et al. 1993; White et al. 2005) and Eburru, Kenya (Ren et al. 2006).

\section{Geochemistry}

Analyses of glass matrices and of glass (melt) inclusions in feldspar phenocrysts are given in Table 4 and Supplementary Table 1 . Before describing the variations, we assess the possibility that the $\mathrm{Na}_{2} \mathrm{O}$ contents do not represent the pristine values. Figure 6 shows the relationship between $\mathrm{Na}_{2} \mathrm{O}$ and $\mathrm{FeO}^{*}$ in non-hydrated peralkaline obsidians (Macdonald 1974a). Extrapolation of the relationships suggests that at 16 wt. $\% \mathrm{FeO}^{*}$, glasses should contain $\sim 8$

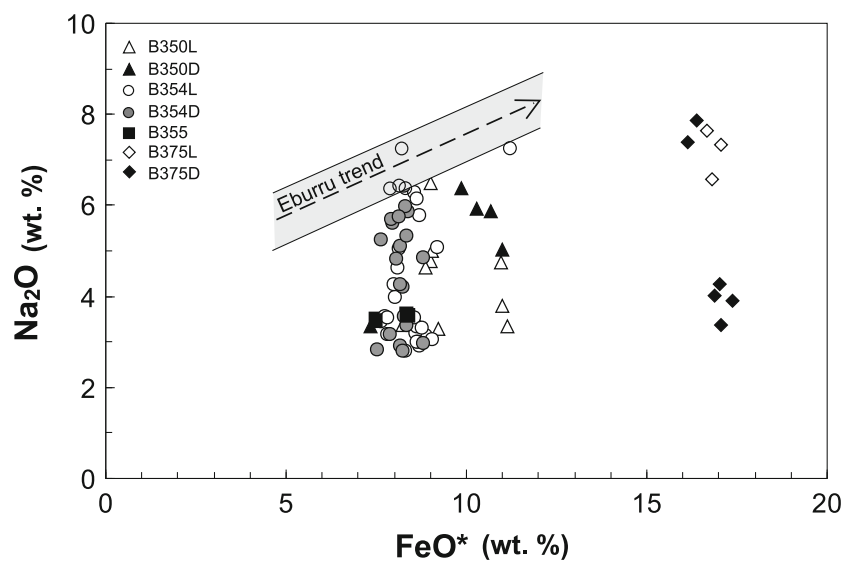

Fig. 6 Plot of $\mathrm{Na}_{2} \mathrm{O}$ against $\mathrm{FeO}$. The shaded field encloses the compositions of $95 \%$ of non-hydrated peralkaline silicic obsidians compiled by Macdonald (1974a). The arrowed trend is for the glasses synthesised by Scaillet and Macdonald (2006) in a pantellerite obsidian from the Eburru volcanic complex. The majority of Boseti glasses fall below the obsidian field, suggesting that they have lost some $\mathrm{Na}$ relative to their pristine melt compositions. Data from Supplementary Table 1

9 wt. $\% \mathrm{Na}_{2} \mathrm{O}$. This is exemplified by the glasses synthesised from an Eburru pantellerite (Scaillet and Macdonald 2006). Many of the Boseti matrix glass analyses fall below the band defined by the obsidians. Four explanations seem possible. First, the Boseti rhyolitic magmas were relatively Na-poor; this possibility is unlikely because the Boseti basalts are actually sodic (Ronga et al. 2010). Second, the glasses have lost variable amounts of $\mathrm{Na}$ during microprobe analysis; Morgan and London (2005) have shown that peralkaline glasses with high contents of $\mathrm{F}$ and $\mathrm{Cl}$ are particularly prone to Na migration, a point made also by Mungall and Martin (1996). Although we were very careful about maximising the probe conditions for $\mathrm{Na}$ analysis, we cannot totally preclude some Na loss under the beam. Third, the microprobe beam included microlites. Since feldspar and aegirine-augite are common microlites and both contain $\mathrm{Na}$, this effect is unlikely. Fourth, the glasses have experienced variable degrees of secondary hydration. Three of the whole-rocks of our rocks have LOI between $1.1 \mathrm{wt} . \%$ and $2.1 \mathrm{wt} . \%$ (Ronga et al. 2010); since most of that is incorporated in the matrix glass, it is possible that $\mathrm{Na}$ has been lost by this mechanism. An additional complication is that although melt inclusions in phenocrysts may have avoided secondary hydration, their compositions may have been modified by post-entrapment crystallization, undetected in our BSE images.

To deal with the problem of $\mathrm{Na}$ loss, we use the alternative measure of peralkalinity, FK/A $(\mathrm{mol} .(\mathrm{Fe}+\mathrm{K}) /$ $\mathrm{Al}$, with all $\mathrm{Fe}$ calculated as $\mathrm{Fe}^{2+}$ ), where $\mathrm{FeO}^{*}, \mathrm{~K}_{2} \mathrm{O}$ and $\mathrm{Al}_{2} \mathrm{O}_{3}$ are considered to be relatively immobile (White et al. 2003). An excellent correlation between PI and FK/A was found for the comenditic obsidians of the Olkaria complex 
(Marshall et al. 2009) and there is also an excellent correlation between the parameters in the experimental glasses from Eburru (Scaillet and Macdonald 2006). Revised $\mathrm{Na}_{2} \mathrm{O}$ values for the Boseti glasses, were calculated from the FK/A ratio and are in good agreement (to within 0.5 wt.\%) with those estimated from the $\mathrm{Na}_{2} \mathrm{O}-\mathrm{FeO} *$ plot (Fig. 6). The revised values were then used to calculate revised PI, which are given in Table 4.

We obtained one analysis of a melt inclusion and only one satisfactory matrix glass analysis in the largely devitrified B355. The analyses are broadly similar (Table 4), the melt inclusion perhaps being slightly less evolved, with lower $\mathrm{SiO}_{2}$ and higher $\mathrm{Al}_{2} \mathrm{O}_{3}$ and $\mathrm{CaO}$ contents, consistent with trapping during the earliest stages of crystallization. In $\mathrm{B} 350$, the darker and lighter glasses are compositionally different, most notably in the $\mathrm{Al}_{2} \mathrm{O}_{3}$ (7.88 and 5.36 wt.\%) and $\mathrm{FeO}^{*}$ (8.89 and 11.03 wt.\%) abundances. Melt inclusions in feldspar phenocrysts from the dark and lighter glass areas are similar and have been averaged together in Table 3; they are transitional in composition between the darker and lighter matrix glasses. Except for $\mathrm{CaO}$, where the averages are $0.42 \mathrm{wt} \%$ (lighter) and $0.20 \mathrm{wt} . \%$ (darker), there are no significant differences between the darker and lighter matrix glasses in B354, as shown both by random analyses in each type and by two detailed profiles across the boundary between them (Supplementary Table 1). One profile revealed a point analysis of a glass component which is less evolved ( $q$ 19.6\%) than the other glasses and the whole-rock composition $(q \sim 30 \%)$. A melt inclusion is similar to the matrix glasses. There are also no significant differences between the darker and lighter components in B375. The most extreme glass compositions are those forming small $(<100 \mu \mathrm{m})$ pools rimming feldspar phenocrysts and in the matrix, the main features being the low $\mathrm{Al}_{2} \mathrm{O}_{3}$ (average $=\sim 2.3$ wt.\%) and high $\mathrm{FeO}^{*}$ (average $\sim 16.8$ wt.\%) contents. The average PI is 7.0, considerably higher than the values for the lowest-temperature experimental glasses synthesised from Eburru (3.7; Scaillet and Macdonald 2006) and Pantelleria (3.2, Di Carlo et al. 2010) pantellerites. The relatively low $\mathrm{SiO}_{2}$ abundance ( $\sim 65$ wt.\%) leads to the glass being classified as trachyte in the TAS system (Le Bas et al. 1986), despite a $q$ value of $32.1 \%$, a useful reminder of the limitations of using $\mathrm{SiO}_{2}$ as a differentiation index in peralkaline silicic rocks.

The Boseti glasses are moderately $\mathrm{Cl}$ rich, up to $0.5 \mathrm{wt} . \%$. Abundances in the darker glass are slightly higher than in the lighter glass in both B350 and B354 (Table 4). We have only limited $\mathrm{F}$ data, which vary from 0.10 to $0.52 \mathrm{wt} . \%$ (Table 4). Differences between the light and dark glasses in B350 and B375 are within analytical error. The $\mathrm{F}$ content of the residual glass in B375 (0.5 wt.\%) is much lower than expected from closed-system fractionation of the host-rock. It is possible that $\mathrm{F}$ has been degassed in a volatile phase but the glasses are non-vesicular. Furthermore, F partitions strongly into the melt phase during crystallization of peralkaline rhyolites (Webster et al. 1995; Barclay et al. 1996). Neither has a F-rich phase crystallized, unless we have not recognised fluorite, which has been found as phenocrysts in the Olkaria comendites (Marshall et al. 1998).

\section{Discussion}

Significance of glass analyses

Our new glass analyses, and analyses of a range of highly evolved natural and experimental glasses and whole-rocks, are shown on an $\mathrm{FeO} *-\mathrm{Al}_{2} \mathrm{O}_{3}$ plot in Fig. 7. Tie-lines connect whole-rocks and matrix glasses. Predictably, the matrix glasses are, with one exception, more evolved (higher Fe, lower $\mathrm{Al}$ ) than their host rock. The exception is $\mathrm{B} 354$, where the higher $\mathrm{Al}_{2} \mathrm{O}_{3}$ in the glass cannot be explained by crystallization of alkali feldspar, the only phenocryst phase. It may be that the whole-rock composition reported by Ronga et al. (2010) has been wrongly labelled.

Our new data (Table 4) confirm the range of glass compositions established by Ronga et al. (2010), particularly the exceptionally low $\mathrm{Al}_{2} \mathrm{O}_{3}$ contents and high $\mathrm{FeO}^{*}$ contents. Broadly similar glass compositions have been recorded in natural eruptive rocks and in experiments on pantellerites (Fig. 7). Lacroix (1930) presented an analysis

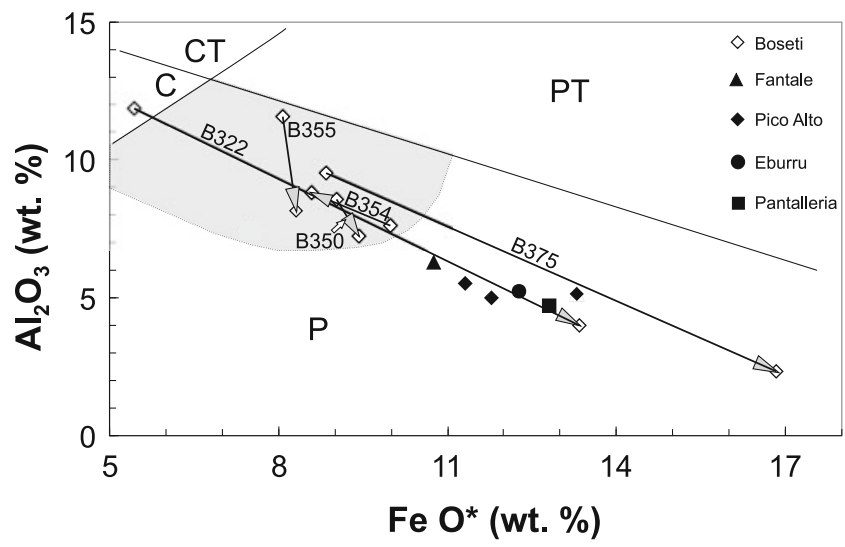

Fig. 7 Glasses from various suites plotted on an $\mathrm{FeO} *-\mathrm{Al}_{2} \mathrm{O}_{3}$ diagram. The fields of comenditic trachyte (CT), comendite (C), pantelleritic trachyte (PT) and pantellerite $(\mathrm{P})$ are from Macdonald (1974a). Tie-lines connect matrix or experimental glasses and host whole-rocks. For Boseti rocks with $>1$ glass component, the values used here are averages weighted by the estimated abundance of each component. Data sources: Boseti, whole-rocks, Ronga et al. (2010), glasses, this paper; Pantelleria, whole-rock and most $\mathrm{FeO}^{*}$-rich experimental glass, Di Carlo et al. (2010, no. 6-7); matrix glasses and melt inclusions from pantellerites of Pico Alto, Terceira, Mungall and Martin (1996); Fantale obsidian, Ethiopia, Lacroix (1930). The shaded field encloses the field of natural pantellerite obsidians, updated from Macdonald (1974a) 
of a pantellerite obsidian from the Fantale volcano, Ethiopia, with 6.26 wt. $\% \mathrm{Al}_{2} \mathrm{O}_{3}$ and 10.75 wt.\% FeO*. Melt inclusions in fayalite phenocrysts and intratelluric glass in partially crystallised pantellerites of the Pico Alto volcano, Terceira, Azores, have $\mathrm{Al}_{2} \mathrm{O}_{3}$ as low as 5.00 wt.\% and $\mathrm{FeO}$ up to 13.29 wt.\% (Mungall and Martin 1996). The most evolved glass produced experimentally from an Eburru pantellerite had 5.22 wt.\% $\mathrm{Al}_{2} \mathrm{O}_{3}$ and 12.27 wt.\% $\mathrm{FeO}^{*}$, the glass representing 53.8\% residual melt (Scaillet and Macdonald 2006). Similarly, Di Carlo et al. (2010) recorded that the most evolved experimental glass from a Pantellerian pantellerite had 4.72 wt.\% $\mathrm{Al}_{2} \mathrm{O}_{3}, \mathrm{FeO}^{*}$ 12.8 wt. $\%$, with $30 \%$ modal glass.

The fact that natural and experimental glasses broadly converge on a composition around 5 wt. $\% \mathrm{Al}_{2} \mathrm{O}_{3}$ and 13 wt. $\% \mathrm{FeO}^{*}$ seems to suggest that they have approached the true near-minimum melt composition of peralkaline oversaturated systems (c.f. Scaillet and Macdonald 2006). In detail, there is a range of compositions; at 5 wt. $\% \mathrm{Al}_{2} \mathrm{O}_{3}, \mathrm{FeO} *$ contents range from $\sim 12$ wt. $\%$ to 14 wt. $\%$ (Fig. 7) and $\mathrm{SiO}_{2}$ from 64 wt. $\%$ to 68 wt. $\%$. There is probably not, therefore, a unique minimum point, the range reflecting such factors as the point at which quartz begins to crystallize (perhaps controlled by $\mathrm{P}, p \mathrm{H}_{2} \mathrm{O}$ and the $\mathrm{F} / \mathrm{Cl}$ ratio), and whether magnetite or ilmenite was the stable oxide. The glass in B375 $\left(\mathrm{Al}_{2} \mathrm{O}_{3} 2.39\right.$ wt.\%) indicates that even more extreme melt compositions can be reached, albeit in tiny amounts. The $\sim 5$ wt. $\% \quad \mathrm{Al}_{2} \mathrm{O}_{3}$ compositions can then be seen as effective minima, i.e. compositions reached in experiments and occasionally as matrix glasses but which have been erupted as a rock only once, at Fantale volcano, Ethiopia (Lacroix 1930). It is important to stress that these highly evolved compositions are reached by the fractionation of alkali feldspar + fayalite + hedenbergite + oxide \pm quartz assemblages, the dominant assemblage in peralkaline trachytes and rhyolites.

The scarcity of such strongly peralkaline melts as eruptive rocks is probably a result of relatively high density caused by their high $\mathrm{FeO}^{*}$ and low $\mathrm{SiO}_{2}$ contents. Allied to their low volumes, this inhibits crustal ascent and the melts get trapped at depth (Scaillet and Macdonald 2006). Eruption may require explosive activity; the most differentiated compositions may therefore occur as pyroclastic, especially ash fall, deposits. This has been shown at the Menengai trachyte volcano (Leat et al. 1984) and the Olkaria rhyolitic complex (Marshall et al. 2009) but we are unaware of any published, systematic geochemical study of the fall deposits in a pantellerite centre.

Feldspar-melt relationships

Our aim of describing feldspar-melt relationships in the Boseti rocks is hampered by uncertainties over the $\mathrm{Na}_{2} \mathrm{O}$ contents of the glasses. Using, however, the $\mathrm{Na}_{2} \mathrm{O}$ values calculated from the FK/A ratios, some points may usefully be made. The range of Or contents in the phenocrysts

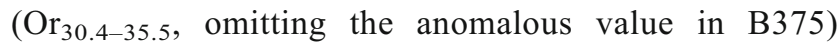
approaches the value of $\mathrm{Or}_{36}$ recorded by Di Carlo et al. (2010) as coexisting with the most evolved glass in their experiments on a Pantellerian pantellerite. The range is also close to the minima between the anorthoclase and sanidine solid solution loops at 1 atm. (anhydrous) pressure $\left(\mathrm{Or}_{35}\right.$; Schairer 1950) and at $1 \mathrm{~kb}$ water pressure $\left(\mathrm{Or}_{30}\right.$; Bowen and Tuttle 1950). It has long been known (Bailey 1974; Roux and Varet 1975) that peralkaline rhyolites with PI up to $\sim 2$ are in equilibrium with feldspar of "minimum" composition. The Boseti and experimental Eburru and Pantelleria data indicate that this relationship seems to persist into the most strongly peralkaline compositions, with PI exceeding 3. Furthermore, the matrix feldspar coexisting with glass in B375 averages $\mathrm{Or}_{35}$ (Table 2; Supplementary Table 1); if we can assume that they are in equilibrium, the feldspar has remained at the minimum composition.

In Fig. 8, $\mathrm{X}$ is $\mathrm{K} /(\mathrm{K}+\mathrm{Na})$ and $\mathrm{Y}$ is $(\mathrm{Si} / 3 \mathrm{Al})-1$, representing the degree of silica-enrichment over an alkali feldspar composition (Roux and Varet 1975). Tie-lines connect feldspar phenocrysts and coexisting matrix glass in B350, B354 and B355. The feldspars are more potassic than the glass, demonstrating the orthoclase effect of Bailey and Schairer (1964) whereby crystallization of feldspar results in strong Na-enrichment in residual melts. The important point, demonstrated for the first time in a natural sequence, is that the orthoclase effect operates even when the melt has reached a PI over 3 .

The composition of the matrix glass in B375 is also of considerable interest. The feldspar-glass tie-line is at an

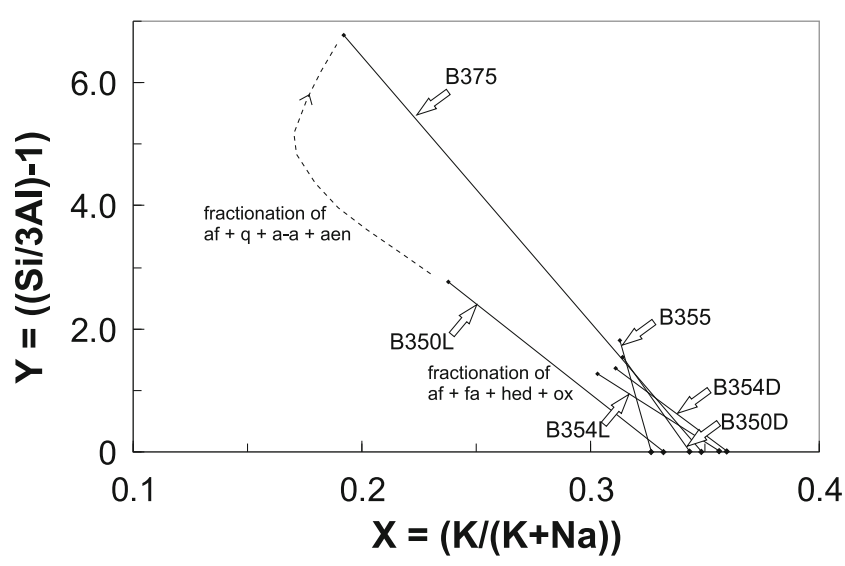

Fig. 8 Plot of $X(\mathrm{~K} /(\mathrm{K}+\mathrm{Na}))$ against $\mathrm{Y}((\mathrm{Si} / 3 \mathrm{Al})-1)$ (Roux and Varet 1975) to show the relationship between the alkali ratio and silicaenrichment in the Boseti matrix glasses and Or content of the coexisting alkali feldspar phenocrysts. Tie-lines connect matrix glass and feldspar; D and L refer to darker and lighter glasses in mixed rocks 
angle to those in the other rocks, a result of the crystallization of aegirine and aenigmatite prior to glass formation (Fig. 8), muting the Na-enrichment. Whilst the glass points to the trend potentially followed during extreme fractionation of peralkaline rhyolite, we stress that we know of no natural volcanic sequence where compositional variations due to fractionation of aegirine and/or aenigmatite have been convincingly demonstrated (c.f. Macdonald 1974b).

\section{Magma mixing}

The occurrence of magma mixing in the Boseti peralkaline rhyolites is most clearly shown by the petrographic and geochemical evidence of mingling outlined earlier (Fig. 2), including: (i) the occurrence in B355 and B175 of feldspar phenocrysts of cores of $\mathrm{Or}_{16-19}$, and in B355 of a relatively magnesian core to a clinopyroxene phenocryst $\left(\mathrm{Ca}_{44.9} \mathrm{Mg}_{21.1} \mathrm{Fe}_{34.0}\right)$, values consistent with crystallization from a more mafic trachyte or benmoreite; (ii) the presence of resorbed feldspar and olivine phenocrysts; and (iii) the local presence of glass in B354 less evolved than the bulkrock. Magma mixing is very common in peralkaline silicic systems, having been recorded at, inter alia, Longonot, Kenya (Scott and Bailey 1986), Menengai, Kenya (Leat et al. 1984), SW Sardinia, Italy (Morra et al. 1994), Pantelleria, Italy (Ferla and Meli 2006), Gedemsa, Ethiopia (Peccerillo et al. 2003), and Olkaria, Kenya (Macdonald et al. 2008b). The process involves 2-, 3- or 4-component mixing of various combinations of basalt, mugearite, trachyte and rhyolite and occurs both in the magma reservoirs and in volcanic conduits. The mixing attests to the open nature of such systems. In noting the occurrence of rhyolite-rhyolite and rhyolite-trachyte/mugearite mixing at Boseti, we suggest that further study will find evidence of a basaltic component in many rocks. We further suggest that the intimate mixing of trachytic and pantelleritic magmas in the complex indicates the existence of compositionally zoned magma reservoirs.

Acknowledgements Harevy Belkin and an anonymous reviewer provided very helpful comments on the original manuscript. We also thank Ms Lidia Jeżak for aid in electron microprobe analysis. We acknowledge financial support from the University of Warsaw.

Open Access This article is distributed under the terms of the Creative Commons Attribution Noncommercial License which permits any noncommercial use, distribution, and reproduction in any medium, provided the original author(s) and source are credited.

\section{References}

Bailey DK (1974) Experimental petrology relating to oversaturated peralkaline volcanics: a review. Bull Volcanol 38:637-652

Bailey DK, Schairer JF (1964) Feldspar-liquid equilibria in peralkaline liquids - the orthoclase effect. Am J Sci 262:1198-1206
Barclay J, Carroll MR, Houghton BF, Wilson CJN (1996) Pre-eruptive volatile content and degassing history of an evolving peralkaline volcano. J Volcanol Geotherm Res 74:75-87

Bowen NL, Tuttle OF (1950) High temperature albite and contiguous feldspars. J Geol 58:572-583

Brotzu P, Morbidelli L, Piccirillo EM, Traversa G (1974) Petrological features of Boseti mountains, a complex volcanic system in the axial portion of the Main Ethiopian Rift. Bull Volcanol 38:206234

Brotzu P, Morbidelli L, Piccirillo EM, Traversa G (1978) Geological map of Boseti volcanic complex (Main Ethiopian Rift). SELCA, Firenze

Brotzu P, Morbidelli L, Piccirillo EM, Traversa G (1980) Volcanological and magmatological evidence of the Boseti volcanic complex (Main Ethiopian Rift). Acc Naz Lincei (Roma) 47:317362

Carmichael ISE (1962) Pantelleritic liquids and their phenocrysts. Mineral Mag 33:86-113

Crisp JA, Spera F (1987) Pyroclastic flows and lavas of the Mogan and Fatima formations, Tejeda Volcano, Gran Canaria, Canary Islands: mineral chemistry, intensive parameters, and magma chamber evolution. Contrib Mineral Petrol 96:503-518

Di Carlo I, Rotolo S, Scaillet B, Buccheri V, Pichavant M (2010) Phase equilibrium constraints on pre-eruptive conditions of Recent felsic explosive volcanism at Pantelleria Island, Italy. J Petrol 51:2245-2276

Di Paola GM (1972) The Ethiopian Rift Valley (between $7^{\circ} 00^{\prime}$ long E. and $8^{\circ} 40^{\prime}$ lat. N). Bull Volcanol 36:517-560

Ferla P, Meli C (2006) Evidence of magma mixing in the 'Daly gap' of alkaline suites: a case study from the enclaves of Pantelleria (Italy). J Petrol 47:1467-1507

Gibson IL (1974) A review of the geology, petrology and geochemistry of the volcano Fantale. Bull Volcanol 38:791-802

Kilinc A, Gerke T (2003) Compositional dependency of Fe-Mg exchange between olivine and melt. Geol Soc Amer, Abstr 35 (6): 72

Lacroix A (1930) Les roches hyperalcalines du Massif du Fantale et du col de Balla. Mém Soc Géol France 14:89-102

Leat PT, Macdonald R, Smith RL (1984) Geochemical evolution of the Menengai caldera volcano, Kenya. J Geophys Res 89:85718592

Le Bas MJ, Le Maitre RW, Streickesen A, Zanettin B (1986) A chemical classification of volcanic rocks based on the total alkalisilica diagram. J Petrol 27:745-750

Lowenstern JB, Mahood GA, Hervig RL, Sparks J (1993) The occurrence and distribution of Mo and molybdenite in unaltered peralkaline rhyolites from Pantelleria, Italy. Contrib Mineral Petrol 114:119-129

Macdonald R (1974a) Nomenclature and petrochemistry of the peralkaline oversaturated extrusive rocks. Bull Volcanol 38:498516

Macdonald R (1974b) The rôle of fractional crystallization in the formation of the alkaline rocks. In: Sørensen H (ed) The alkaline rocks. Wiley, London, pp 442-459

Macdonald R, Bagiński B, Belkin HE, Dzierżanowski P, Jeżak L (2008a) REE partitioning between apatite and melt in a peralkaline volcanic suite, Kenya Rift Valley. Mineral Mag 72:11471161

Macdonald R, Belkin HE, Fitton JG, Rogers NW, Nejbert K, Tindle AG, Marshall AS (2008b) The roles of fractional crystallization, magma mixing, crystal mush remobilization and volatile-melt interactions in the genesis of a young basalt-peralkaline rhyolite suite, the Greater Olkaria Volcanic Complex, Kenya Rift Valley. J Petrol 49:1515-1547

Macdonald R, Bagiński B, Leat PT, White JC, Dzierżanowski P (2011) Mineral stability in peralkaline silicic rocks: information 
from trachytes of the Menengai volcano, Kenya. Lithos 125:553568

Mahood GA, Stimac JA (1990) Trace-element partitioning in pantellerites and trachytes. Geochim Cosmochim Acta 54:2257-2276

Marshall AS, Hinton RW, Macdonald R (1998) Phenocrystic fluorite in peralkaline rhyolites, Olkaria, Kenya Rift Valley. Miner Mag 62:477-486

Marshall AS, Macdonald R, Rogers NW, Fitton JG, Tindle AG, Hinton RW (2009) Fractionation of peralkaline silicic magmas: the Greater Olkaria Volcanic Complex, Kenya Rift Valley. J Petrol 50:323-359

Morgan GBVI, London D (2005) Effects of current density on the electron microprobe analysis of alkali aluminosilicate glasses. Am Mineral 90:1131-1138

Morra V, Secchi FA, Assorgia A (1994) Petrogenetic significance of peralkaline rocks from Cenozoic calcalkaline volcanism from SW Sardinia, Italy. Chem Geol 118:109-142

Mungall JE, Martin RF (1996) Extreme differentiation of peralkaline rhyolite, Terceira, Azores: a modern analogue of Strange Lake, Labrador? Can Mineral 34:769-777

Peccerillo A, Barberio MR, Yirgu G, Ayalew D, Barbieri M, Wu TW (2003) Relationships between mafic and peralkaline silicic magmatism in continental rift settings: a petrological, geochemical and isotopic study. J Petrol 44:2003-2032

Pouchou JL, Pichoir JF (1991) Quantitative analysis of homogeneous or stratified microvolumes applying the model 'PAP'. In: Newbury $\mathrm{H}$ (ed) Electron probe quantitation. Plenum Press, New York, pp 31-75

Putirka KD, Mikaelian H, Ryerson F, Shaw H (2003) New clinopyroxene-liquid thermobarometers for mafic, evolved, and volatile-bearing lava compositions, with applications to lavas from Tibet and the Snake River Plain, Idaho. Am Mineral 88:1542-1554

Ren M, Omenda PA, Anthony EY, White JC, Macdonald R, Bailey DK (2006) Application of the QUILF thermobarometer to the peralkaline trachytes and pantellerites of the Eburru volcanic complex, East African Rift, Kenya. Lithos 91:109-124

Roeder PL, Emslie RF (1970) Olivine-liquid equilibrium. Contrib Mineral Petrol 29:275-289

Ronga F, Lustrino M, Marzoli A, Melluso L (2010) Petrogenesis of a basalt-comendite-pantellerite rock suite: the Boseti volcanic complex (Main Ethiopian Rift). Mineral Petrol 98:227-243
Roux J, Varet J (1975) Alkali feldspar liquid equilibrium relationships in peralkaline oversaturated systems and volcanic rocks. Contrib Mineral Petrol 49:67-81

Scaillet B, Macdonald R (2001) Phase relations of peralkaline silicic magmas and petrogenetic implications. J Petrol 42:825-845

Scaillet B, Macdonald R (2003) Experimental constraints on the relationships between peralkaline rhyolites of the Kenya Rift Valley. J Petrol 44:1867-1894

Scaillet B, Macdonald R (2006) Experimental evidence on preeruption conditions of pantelleritic magmas: evidence from the Eburru complex, Kenya Rift. Lithos 91:95-108

Schairer JF (1950) The alkali-feldspar join in the system $\mathrm{NaAlSi}_{3} \mathrm{O}_{8^{-}}$ $\mathrm{KAlSi}_{3} \mathrm{O}_{8}-\mathrm{SiO}_{2}$. J Geol 58:512-517

Scott SC, Bailey DK (1986) Coeruption of contrasting magmas and temporal variations in magma chemistry at Longonot volcano, Central Kenya. Bull Volcanol 47:849-873

Sisson TW, Grove TL (1993) Experimental investigations of the role of $\mathrm{H}_{2} \mathrm{O}$ in calc-alkaline differentiation and subduction zone magmatism. Contrib Mineral Petrol 113:143-166

Troll VR, Schmincke H-U (2002) Magma mixing and crustal recycling recorded in ternary feldspar from compositionally zoned peralkaline ignimbrite 'A', Gran Canaria, Canary Islands. J Petrol 43:243-270

Ulmer P (1989) The dependence of the $\mathrm{Fe}^{2+-} \mathrm{Mg}$ cation partitioning between olivine and basaltic liquid on pressure, temperature and composition: an experimental study to 39 kbars. Contrib Mineral Petrol 101:261-273

Webster JD, Taylor RP, Bean C (1995) Pre-eruptive melt composition and constraints on degassing of a water-rich pantellerite magma, Fantale volcano, Ethiopia. Contrib Mineral Petrol 114:53-62

White JC, Holt GS, Parker DF, Ren M (2003) Trace-element partitioning between alkali feldspar and peralkalic quartz trachyte to rhyolite magma. Part 1: systematics of trace-element partitioning. Am Mineral 88:316-329

White JC, Parker DF, Ren M (2009) The origin of trachyte and pantellerite from Pantelleria, Italy: insights from major element, trace element, and thermodynamic modelling. J Volcanol Geotherm Res 179:33-55

White JC, Ren M, Parker DF (2005) Variation in mineralogy, temperature, and oxygen fugacity in a suite of strongly peralkaline lavas and tuffs, Pantelleria, Italy. Can Mineral 43:1331-1347 